\title{
USE OF DOPAMINE AGONIST IN TETANUS SPASMS - A NOVEL APPROACH TO REVERT THE RESPIRATORY SPASM - THE CAUSE OF MORTALITY
}

\author{
VINOD KUMAR ${ }^{1}$, ABHISHEK GUPTA ${ }^{1}$, DEVESH JOHARI ${ }^{1}$, and LORI TEWARI ${ }^{1}$ \\ ${ }^{1}$ ADVANCE NEURO AND GENERAL HOSPITAL
}

July 1, 2020

\begin{abstract}
In tetanus patients Levodopa and Carbidopa combination (which is usually used to relieve the signs of extrapyramidal) causes respiratory muscles spasm relief thereby the need for sedatives is decreased and patient saved later on via central nervous system mechanism, by providing the inhibitory neurotransmitters at Anterior Horn cells.
\end{abstract}

\section{MANUSCRIPT TITLE}

USE OF DOPAMINE AGONIST IN TETANUS SPASMS - A NOVEL APPROACH TO REVERT THE RESPIRATORY SPASM - THE CAUSE OF MORTALITY

The author(s) name(s) and affiliation(s), and corresponding author details (name, affiliation, mailing address and email address).

CONTRIBUTORS:

1. DR VINOD KUMAR TEWARI (CORROSPONDING AUTHOR) MCh NEUROSURGEON DIRECTOR ADVANCE NEURO AND GENERAL HOSPITAL, ARJUNAGANJ. LUCKNOW. UP. INDIA. 226010. CORESSPONDING ADRESS DR VINOD KUMAR TEWARI 5/279 VIPUL KHAND GOMTI NAGAR, LUCKNOW UP INDIA 226010 drvinodtewari@gmail.com 9415022002

2. DR ABHISHEK GUPTA ORTHOPAEDICIAN ADVANCE NEURO AND GENERAL HOSPITAL, ARJUNAGANJ. LUCKNOW. UP. INDIA. 226010. drabhishek_gupta@yahoo.com8952022535

3. DR DEVESH JOHARI MBBS, MS (OPTHALMOLOGIST) ADVANCE NEURO AND GENERAL HOSPITAL, ARJUNAGANJ. LUCKNOW. UP. INDIA. 226010. devesh11johari@gmail.com 9414380556

4. MISS LORI TEWARI ADVANCE NEURO AND GENERAL HOSPITAL, ARJUNAGANJ LUCKNOW. UP. INDIA. 226010. loritewari02@gmail.com 6394635210

\section{Hosted file}

USE OF LEVODOPA WITH CARBIDOPA IN TETANUS.docx available at https://authorea.com/users/ 338456/articles/464461-use-of-dopamine-agonist-in-tetanus-spasms-a-novel-approach-torevert-the-respiratory-spasm-the-cause-of-mortality 